\title{
SÚRLÓDÁSIEGYÜTTHATÓ-MÉRŐKÉSZÜLÉK AUTOMATIZÁLÁSA
}

\section{AUTOMATED DETERMINATION OF FRICTION COEFFICIENT}

\author{
Farmos Rudolf László, ${ }^{1}$ Hodgyai Norbert, ${ }^{2}$ Forgó Zoltán, ${ }^{3}$ Egyed-Faluvégi Erzsébet ${ }^{4}$ \\ Sapientia EMTE, Marosvásárhelyi Kar, Gépészmérnöki Tanszék, Marosvásárhely, Románia \\ ${ }^{1}$ farmos_rudolf@ms.sapientia.ro \\ 2 hodgyai@ms.sapientia.ro \\ ${ }^{3}$ zforgo@ms.sapientia.ro \\ ${ }^{4}$ faluvegi.erzsebet@ms.sapientia.ro
}

\begin{abstract}
The presented research is designed to meet a particular challenge facing the industry. Its aim is to automate the process of friction coefficient determination, using a method that enables quick and easy repeatability of measurements developed by S.C. Plasmaterm S.A in Târgu Mureș.
\end{abstract}

Keywords: friction coefficient, measurement system, automation.

\section{Összefoglalás}

Jelen kutatás az ipar kihívására jött létre. Célja, hogy egy marosvásárhelyi vállalat, a Plasmaterm Rt. által kifejlesztett súrlódásiegyüttható-meghatározó módszert automatizáljon, mely során lehetőség nyílik a gyors és könnyen megismételhető mérésekre, valamint a mérési eredmények kiértékelésére.

Kulcsszavak: súrlódási együttható, mérőkészülék, automatizálás.

\section{Bevezetés}

A jelenkori ipar egyik kihívása, hogy biztosítsa a formamegmunkáló szerszámok hosszú élettartamát. Ez az élettartam arányos a szerszám és a megmunkált fémlemez között fellépő súrlódás jelenségével. Ezért új anyagokat, valamint új felületmegmunkáló eljárásokat fejlesztettek ki. [1] A Plasmaterm Rt. vállalat részt vesz ebben a kutatásban és kidolgozott egy folyamatot, amelynek célja a súrlódási együttható meghatározása. A Sapientia Erdélyi Magyar Tudományegyetem Gépészmérnöki Tanszéke a fent említett mérési folyamat automatizálásának az elvégzésébe kapcsolódott be. A kitüzött cél ennek a folyamatnak az automatizálása.

\section{A kísérleti mérőberendezés}

A mérések a Faville le Vally elvre támaszkodnak [2], amely a test potenciális energiavesztésén alapszik. Ezt úgy határozták meg, hogy egy függőleges kar végére erősített tömeget kilendítenek a karra merőleges tengely körül (kezdeti szög $\alpha_{0}$ ), majd szabadon engedve, az inga túllendül a függőleges helyzeten. Végül megmérik a kitérési szöget a függőlegestől (a túllendülés utáni legnagyobb szög $\alpha$ ). Mivel minden esetben az $\alpha>\alpha 0$, az energiakülönbséget az inga tengelye és ennek alátámasztása közötti súrlódás emészti fel. A fent leírtak alapján a súrlódási együtthatót a következő egyenlet határozza meg: 


$$
\mu=\frac{m}{F} \cdot \frac{R}{D} \cdot \frac{\sqrt{2}}{2} \cdot \frac{\cos \left(\alpha_{0}\right)-\cos (\alpha)}{\alpha-\alpha_{0}}
$$

ahol:

$\mu \quad$ - a kiszámolt súrlódási együttható

$m$ - az erőkar végén levő súly tömege $[\mathrm{kg}]$

F - a próbatestet terhelő erő [N]

$D$ - a próbatest átmérője [m]

$R \quad$ - az erőkar hossza [m]

$\alpha \quad-$ a legnagyobb kitérési szög

$a_{0} \quad$ - a kezdeti szög, ahonnan a súlyt magára hagyjuk

A súrlódási együttható automatizált meghatározására az 1. ábrán látható rendszer szolgál. A berendezés három fő részét lehet megkülönböztetni: a mintát befogó és mozgató eszközt, a folyamatot irányító vezérlőt és az adatgyűjtő/ adatmegjelenítő számítógépet.

A mintát befogó és mozgató eszköznek biztosítania kell a mintadarab pozicionálását, megfelelő terhelését, valamint a minta $400{ }^{\circ} \mathrm{C}$-ra történő melegítését.

A 2. ábra a fent említett befogó- (3. ábra) és mozgatórendszert szemlélteti.

A mérés során a minták (6) a „V” alakú befogópofák (7) közé helyezve, egy pneumatikus mun-

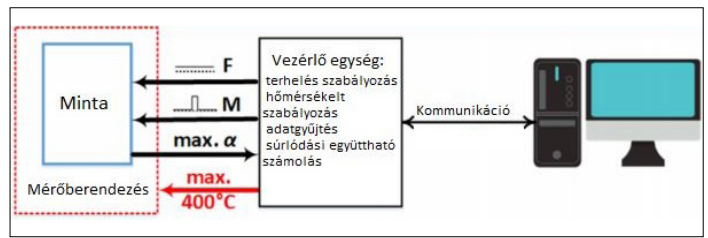

1. ábra. A mérőrendszer elvi felépítése

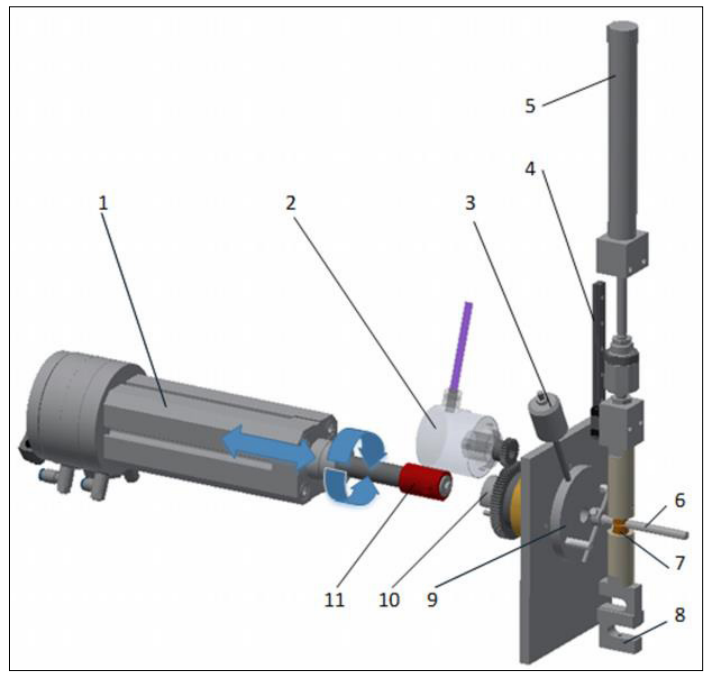

2. ábra. A befogó- és mérörendszer kahenger (5) segítségével egy előre meghatározott erővel lettek megszorítva. A szorítási erő egy mérőcella (8) segítségével mértük. Az erőt beállításához egy proporcionális nyomásszabályzót használtunk. A nyomás beállításával a pneumatikus munkahenger a megfelelő erővel szorította meg a próbatestet. Az inga (3 és 9) biztosította a nyomatékot a minta forgására. A mintatest szögelfordulását az inkrementális jeladó (2) szolgáltatta. A rendszer által szolgáltatott adatok alapján meghatározhatóvá vált a súrlódási együttható.

A rendszer pneumatikus (4. ábra) áramkörének a tervezésekor arra törekedtünk, hogy a rendszer a lehető legegyszerübb legyen.

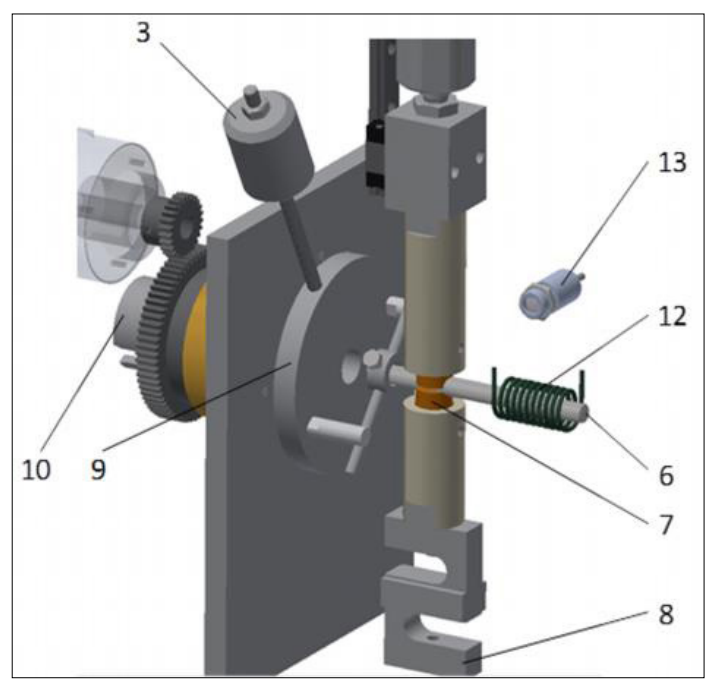

3. ábra. A befogórendszer

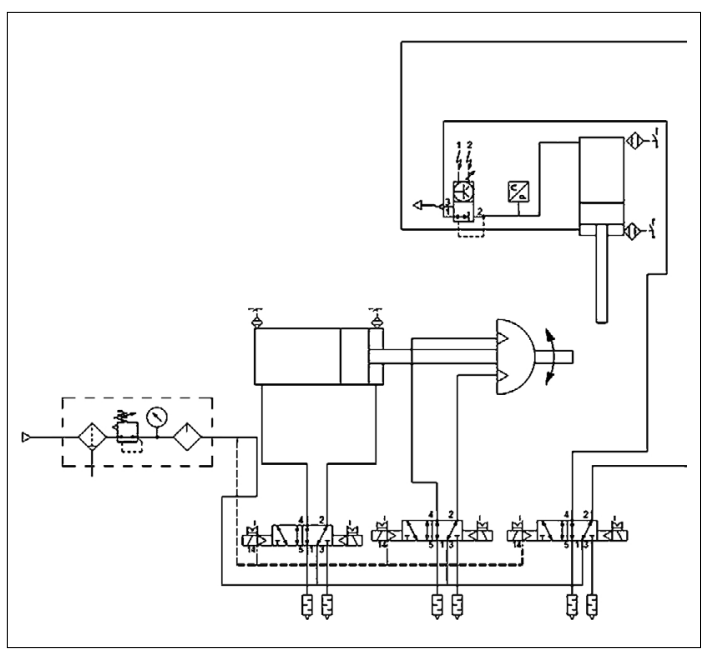

4. ábra. A mérörendszer pneumatikus áramkörének a terve 
A pneumatikus rendszer főbb elemei:

- Levegő-előkészítés (4.1. ábra). Ez az elem felel a rendszerbe érkező levegő üzemi nyomásának a beállításáért, valamint a levegő szárításáért.

- Pozicionálás (4.2. ábra). Ez a modul felel a próbatest pozícióba állításáért. Egy transzlációs (1), valamint egy rotációs (2) mozgást végző pneumatikus munkahenger található ebben a modulban az őket vezérlő két darab 5/2-es (3) szeleppel.

- Szorítás erőszabályozással (4.3. ábra). Ez a modul felel a munkadarab kellő megszorításáért. A szorítást egy transzlációs munkahenger (1) végzi, mértéke egy propocionális nyomásszabályozó (2) segítségével történik. A nyomás mérésére egy analóg nyomásmérő szenzort (3) alkalmaztunk.

A rendszer vezérlője (5. ábra) egy Rexroth L10es logikai vezérlő (PLC). A PLC alapmoduljához kapcsolódik egy távvezérlő, amivel kézi üzemmódban vezérelhető a mérőrendszer.

A PLC-hez kapcsolt digitális és analóg bővítőmodulokhoz kapcsolódnak a munkahengerek végálláskapcsolói, a munkahengereket vezérlő szele-

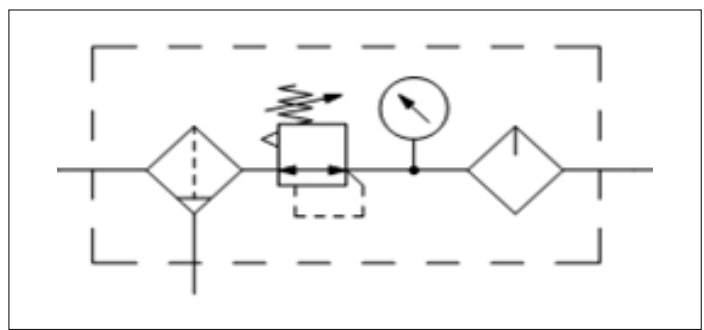

4.1. ábra. A levegő-előkészítő

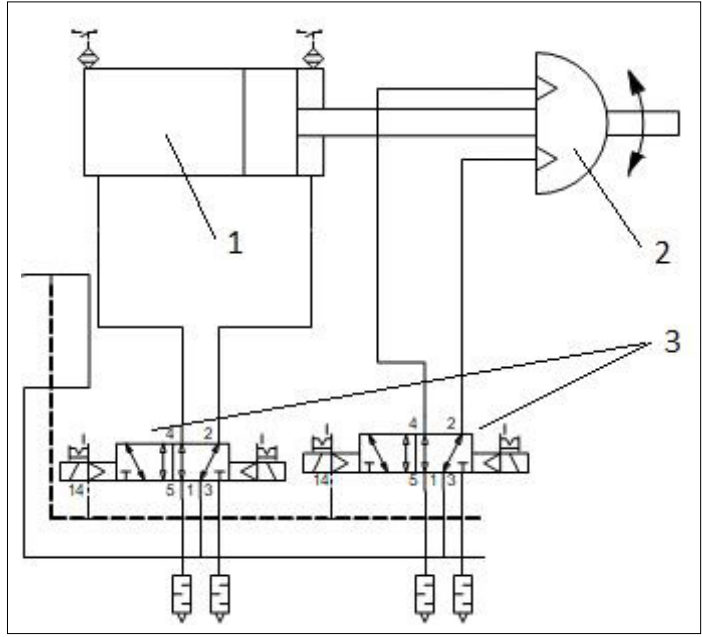

4.2. ábra. A pozicionáló modul pek, az erőmérő cella, egy nyomásmérő szenzor, valamint a proporcionális nyomásszabályozó.

A rendszerhez tartozik még egy adatmegjelenítő program, amely a PLC-vel a saját protokollon keresztül kommunikál. A program az adatmegjelenítésen kívül (6. ábra) adatmentést is végez egy adatbázisba a későbbi adatfeldolgozás céljából.

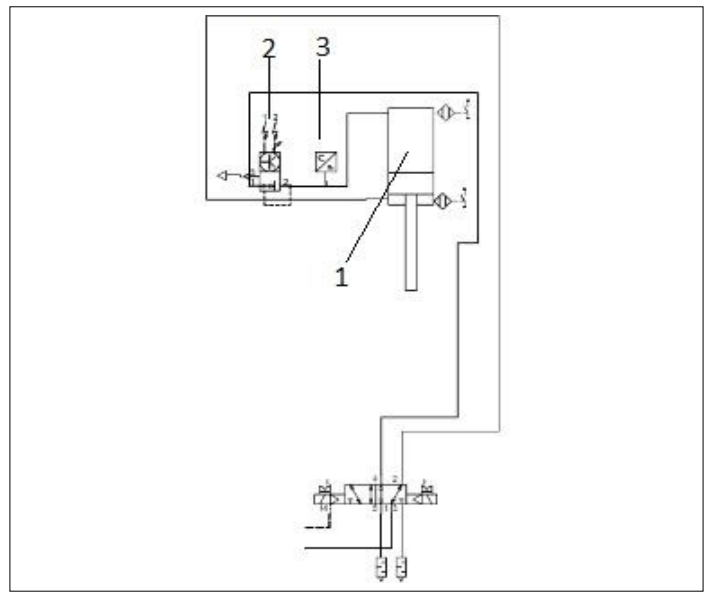

4.3. ábra. A szorító modul

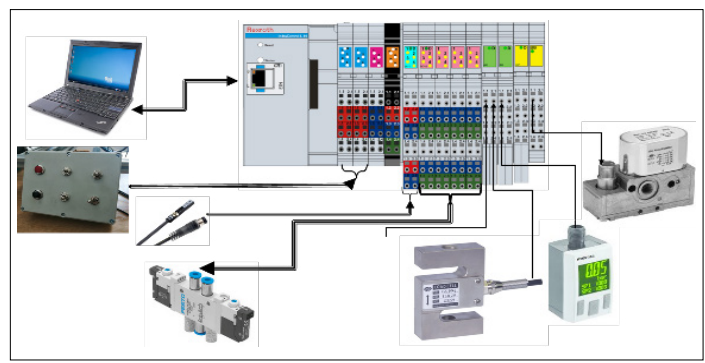

5. ábra. A vezérlörendszer

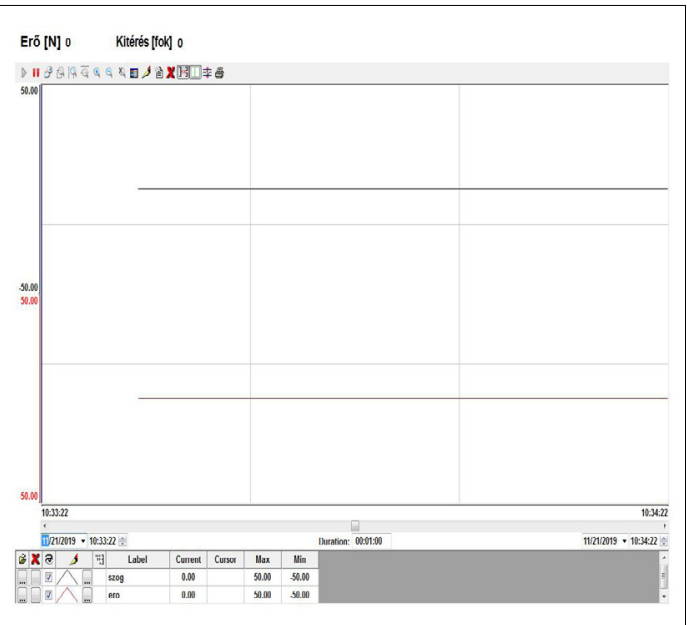

6. ábra. Adatmegjelenítő felület 


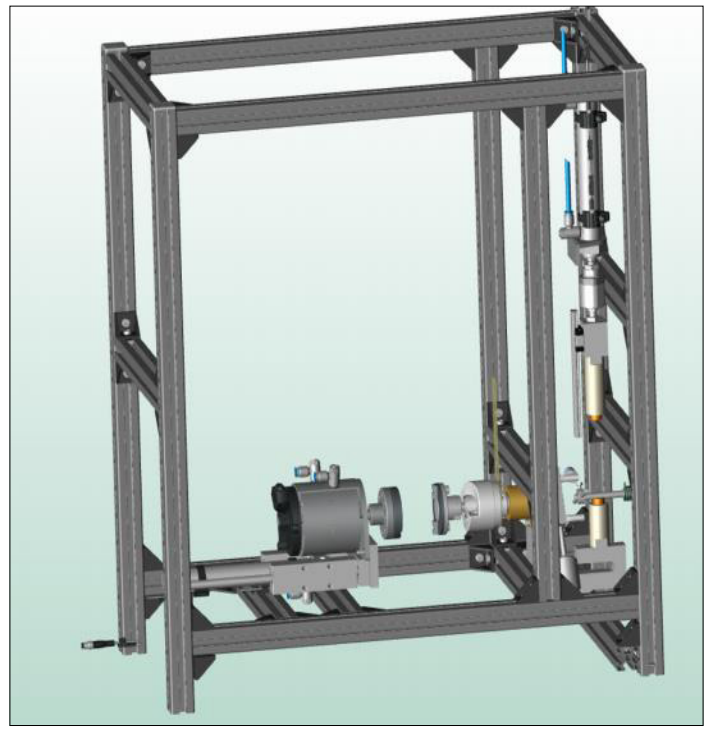

7. ábra. A teljes rendszer 3D-modellje

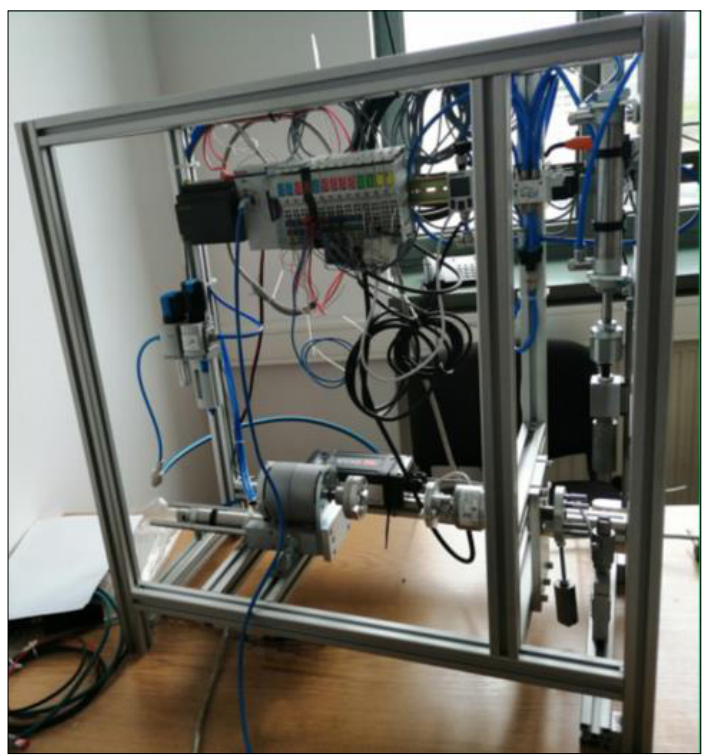

8. ábra. A teljes rendszer

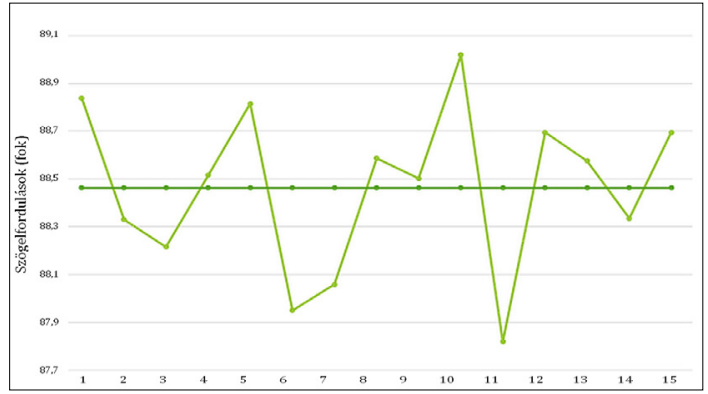

9. ábra. Mérési eredmények acél befogók esetén

A 9. ábrán egy 15 mérésből álló méréssorozat eredménye látható. A próbatest is, valamint a befogópofák is acél anyagúak. Ennél a befogó-próbatest párosításnál a legkisebb kitérés $87,82^{\circ}$, a legnagyobb kitérés $89,02^{\circ}$. Ismerve a 15 mérés átlagát $\left(88,46^{\circ}\right)$, valamint a kiindulási szöget, a próbatest átmérőjét, a terhelőerőt, az erőkar hosszát és az erőkar végén levő test tömegét, az (1)-es képlet segítségével meghatározható a próbatest és a befogópofák közötti súrlódási együttható.

\section{Következtetések}

Az elkészült automatizált rendszer bebizonyította, hogy a mérőrendszer jól automatizálható, ezáltal lehetőség nyílik a gyors és könnyen megismételhető mérésekre, valamint a mérési eredmények kiértékelésére. A rendszer továbbfejleszthető egy indukciós melegítőrendszerrel (12), valamint egy infravörös hőmérséklet-érzékelővel (13), amiknek a segítségével lehetőség nyílik a mintadarab előre meghatározott hőmérsékletre történő melegítésére, így magas hőmérsékleten is lehetséges lesz a súrlódási együttható mérése.

\section{Szakirodalmi hivatkozások}

[1] Bagyinszki Gy., Bitay Enikő: Felületkezelés. EME, Kolozsvár, 2009.

https://doi.org/10.36242/mtf-05

[2] Jánosi S., Kolozsvary Z., Sándor V., Rusu A: A few remarks on plasma nitriding behavior of austenitic and martensitic stainless steels. Heat Treating. Proceedings of the $20^{\text {th }}$ Conference, 1. (2000) 198-207. 